Brazilian Journal

of Chemical

Engineering

\title{
EFFECTIVENESS OF PHOSPHORUS REMOVAL IN AN SBR USING CO-PRECIPITATION WITH FERRIC CHLORIDE, AND ITS EFFECTS ON MICROBIAL ACTIVITY
}

\author{
Rejane H. R. Costa ${ }^{1}$, Blanca M. Villafranca ${ }^{1}$, Caio A. Voltolini ${ }^{1}$, Lorena B. Guimarães ${ }^{1}$, \\ Heike Hoffmann ${ }^{2}$, Viviane F. Velho ${ }^{3}$ and Rodrigo A. Mohedano ${ }^{1 *}$ \\ ${ }^{1}$ Universidade Federal de Santa Catarina, Departamento de Engenharia Sanitária e Ambiental, Florianópolis, SC, Brazil. \\ ORCID: 0000-0002-2429-5777; ORCID: 0000-0002-9047-2604; ORCID: 0000-0002-6425-8620; ORCID: 0000-0001-9831-3547; \\ E-mail: rodrigo.mohedano@ufsc.br - ORCID: 0000-0003-2860-639X \\ ${ }^{2}$ Rotária do Brasil. Florianópolis, SC, Brazil. ORCID: 0000-0002-6453-8323 \\ ${ }^{3}$ Instituto Federal de Educação, Ciência e Tecnologia Catarinense, Campus Camboriú, Camboriú, SC, Brazil. ORCID: 0000-0001-6737-2325
}

(Submitted: August 28, 2018 ; Revised: November 27, 2018 ; Accepted: December 23, 2018)

\begin{abstract}
The present study evaluated the phosphorus removal in a Sequencing Batch Reactor (SBR - 2,500L) used to treat the wastewater from an office building in two steps: phase I-Enhanced biological phosphorus removal (EBPR) and phase II-co-precipitation using $\mathrm{FeCl}_{3}$ as precipitant. The raw sewage presented a high organic load variation ranging from 0.11 (phase I) to 0.66 (phase II) $\mathrm{kgCOD} \cdot \mathrm{m}^{-3} \cdot \mathrm{d}^{-1}$. A better phosphorus removal performance was obtained during co-precipitation (from 19.0 to $1.2 \mathrm{mg} \cdot \mathrm{L}^{-1}=93 \%$ of efficiency) compared with biological removal (from 15.6 to $9.0 \mathrm{mgL}^{-1}=42 \%$ of efficiency). FISH analyses did not demonstrate a strong PAO inhibition; however, nitrifying and denitrifying organisms (NSO and PAE) showed a significant activity reduction during phase II. Therefore, the bench tests made to obtain the oxygen uptake rate (OUR)

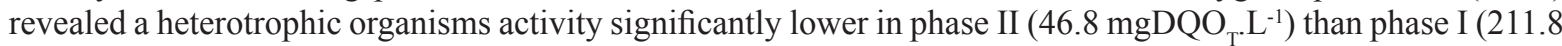
$\left.\mathrm{mgDQO}_{\mathrm{T}} \cdot \mathrm{L}^{-1}\right)$, indicating metabolic inhibition. The co-precipitation processes enhanced phosphorus removal, bringing the SBR effluent into accord with state law requirements; however, the inhibitory effect of ferric chloride on microorganism activity was highlighted.
\end{abstract}

Keywords: Phosphorus removal; Co-precipitation; SBR; Ferric chloride; Microbial activity.

\section{INTRODUCTION}

Nowadays, the high phosphorus loads present in industrial and domestic effluents have caused serious ecological imbalances. When discharged into water bodies without proper treatment, these effluents stimulate primary production, causing several disturbances in oxygen availability. Therefore, the removal of phosphorus compounds from effluents is the key factor to prevent the eutrophication process.

By contrast, removing phosphorus efficiently from sewage is hard work, requiring chemical supplies and accurate operation of wastewater treatment plants
(Metcalf and Eddy, 2003). Thus, researchers around the world have been making efforts to develop and enhance technologies for phosphorus removal from domestic wastewater. This challenge also involves improvement of biological reactor designs to attain a smaller constructed area while saving energy and chemical costs.

In this sense, the sequencing batch reactor (SBR) is possibly the most promising and viable activated sludge variation, designed for removing organic carbon and nutrients such as phosphorus. In a relatively short period, it has become an increasingly popular treatment for domestic and industrial wastewaters. It is known as

\footnotetext{
* Corresponding author: Rejane H. R. Costa - E-mail: rodrigo.mohedano@ufsc.br
} 
a suitable option for decentralized solutions providing effective biological treatment, due to its versatility and operational flexibility (Artan and Orhon, 2005).

Commonly, the removal of phosphate compounds using an SBR occurs through two main pathways: bioaccumulation, and chemical precipitation of poorly soluble compounds (Metcalf and Eddy, 2003). Biological phosphorus removal in SBR based systems depends on the uptake of excess phosphorus by bacteria known as polyphosphate-accumulating organisms (PAOs) (Akin and Ugurlu 2005; Fernandes et al., 2014). This is typically achieved by alternating anaerobic, aerobic, or anoxic conditions (i.e., conditions that use nitrate as an electron acceptor) with biodegradable organic carbon under anaerobic conditions (Wu et al., 2009). Although some uncertainty remains regarding PAO metabolism, it is widely accepted that PAOs gain a competitive advantage over other organisms because of their ability to take up organic carbon (e.g., volatile fatty acids [VFAs]) anaerobically and store it as intracellular polymers (polyhydroxyalkanoates [PHAs]) to process later under either anoxic or aerobic conditions (Schuler and Xiao, 2008). In the subsequent aerobic stage, PAOs oxidize PHAs to obtain energy for growth, glycogen replenishment, and phosphorus uptake (Seviour et al., 2003; Oehmen et al., 2010; Marques et al., 2017).

The concentration of easily biodegradable organic matter is usually insufficient in domestic wastewater for nitrogen and phosphorus removal, resulting in a competition for carbon sources between phosphorus removal and traditional heterotrophic denitrification, which leads to the failure of enhanced biological phosphorus removal (EBPR) in treatment plants (Mielcarek et al., 2015; He et al., 2016).

Therefore, a chemical precipitant is frequently required to supplement phosphorus (P) removal in modified activated sludge systems designed to remove $\mathrm{P}$ biologically, where such systems are unable to achieve the required effluent $\mathrm{P}$ concentration by biological treatment. According to different chemical addition strategies in wastewater treatment plants, the chemically assisted phosphorus removal process can be divided into chemical pre-treatment (chemical is used for enhanced primary treatment), chemical posttreatment (chemical is used for tertiary treatment), and co-precipitation treatment (addition of chemical directly into the biological reactor) (Filali-Meknassi et al. 2005; Cui et al., 2009; Zhang et al., 2013).

According to Filali-Meknassi et al. (2005), coprecipitation is flexible to changing conditions and achieves low effluent phosphate levels. Furthermore, co-precipitation presents advantages as it efficiently removes biological oxygen demand, heavy metals, organic micropollutants and viruses. On the other hand, the simultaneous addition of chemical precipitants such as ferric chloride in aerated reactors may cause inhibition of bacterial metabolism and reduce biological P removal efficiency; however, this is not consensual between authors (De Haas et al., 2000; Sarparastzadeh et al., 2007). Moreover, when large amounts of precipitants are used, a chemical sludge may be generated with potential toxicity (ESPP, 2013).

Thus, the present study aimed to evaluate the biological phosphorus removal and the coprecipitation treatment using ferric chloride $\left(\mathrm{FeCl}_{3}\right)$ to enhance phosphorus removal from sewage in an SBR. In addition, the activity of phosphorus-accumulating organisms (PAOs/DPAOs) and the possibility of metabolic activity inhibition due to $\mathrm{FeCl}_{3}$ addition were also evaluated.

\section{MATERIALS AND METHODS}

\section{SBR design and operation}

This research was carried out through operation and monitoring of a full-scale fiberglass-made sequencing batch reactor (SBR), with a total volume of $2,500 \mathrm{~L}$ (Figure 1A). The SBR was step-fed by sewage from an office building (about 30 individuals) and a family house (5 individuals). The aeration was performed by two diffuser membranes connected to a pump with an air flow rate of $120 \mathrm{~L} . \mathrm{h}^{-1}$. The reaction time in each cycle was defined through previous studies, aimed at the development of PAOs and denitrifying polyphosphate accumulating organisms (DPAOs).

The SBR used a three-step-feed scheme, which was also operated sequentially in an $8 \mathrm{~h}$ cycle, totaling an influent flow rate of 2,100 L.d ${ }^{-1}$ (approximately 700 $\mathrm{L}$ for each cycle). Thus, the total volume treated during each cycle was loaded in three steps of about 230-250L. The three-stage step-feeding was conducted at the beginning of each anoxic stage, aiming to provide an organic carbon source for denitrifying microorganisms (Fernandes et al., 2014 ). The $8 \mathrm{~h}$ cycle consisted of $1 \mathrm{~h} 50 \mathrm{~min}$ anoxic, $20 \mathrm{~min}$ oxic, $1 \mathrm{~h} 50 \mathrm{~min}$ anoxic, $20 \mathrm{~min}$ oxic, $1 \mathrm{~h} 50 \mathrm{~min}$ anoxic, $20 \mathrm{~min}$ oxic, $60 \mathrm{~min}$ settling, and 30 min draw, interspersing denitrification and nitrification conditions during each reaction time ( $2 \mathrm{~h} 10 \mathrm{~min}$ ). The scheme of the operational cycle is shown in Figure 1 (A and B). Additionally, during each anoxic stage, air pulses (turned on every 3 minutes for 5 seconds) were applied to keep the liquid mixed. The SBR operation cycle was totally automatized by a programmable logic controller (PLC - Scadaweb Rotária do Brasil ${ }^{\mathrm{TM}}$ ). The sludge retention time (SRT) was adjusted to 20 days.

The SBR operation was divided into two different phases. In phase I (running for 56 days), P removal was performed by the biological removal process. In phase II (running for 63 days), co-precipitation was conducted to enhance $\mathrm{P}$ removal, applying ferric 


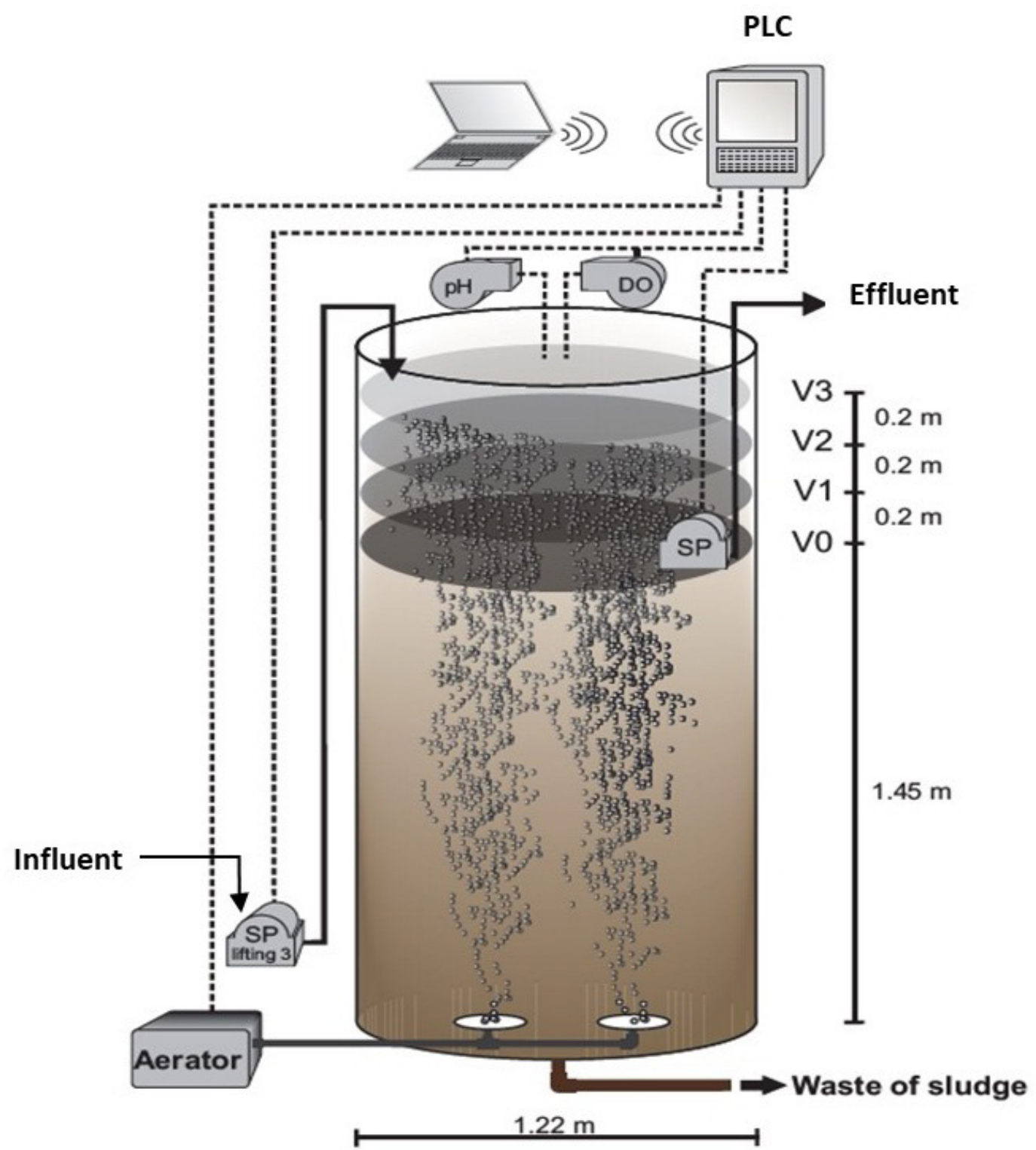

Figure 1. Scheme of the full-scale SBR (A) and operational cycle (A and B): PLC = programmable logic controller; $\mathrm{pH}$ and $\mathrm{DO}=\mathrm{pH}$ and dissolved oxygen probes; $\mathrm{SP}=$ Submersed pump; V0, V1, V2 and V3 = volume of liquid after each filling (three- step filing).

chloride during the last oxic stage (nitrification condition) (Figure 1B). The precipitant solution (196 mg $\left.\mathrm{FeCl}_{3} \cdot \mathrm{L}^{-1}\right)$ was added using a peristaltic pump $\left(\right.$ Exatta $\left.^{\mathrm{TM}}, 20 \mathrm{~L} \cdot \mathrm{min}^{-1}\right)$ with a flow rate of $0.86 \mathrm{~L} \cdot \mathrm{h}^{-1}$ to reach $258 \mathrm{~mL}$ of $\mathrm{FeCL}_{3}$ solution applied per cycle or $774 \mathrm{~mL}$ of $\mathrm{FeCl}_{3}$ per day. Thus, the final concentration in the mixed liquor was approximately $0.072 \mathrm{mg} \mathrm{L}^{-1}$ $\mathrm{FeCl}_{3}$. This dosage was previously tested using jar test assays (data not shown).

\section{Monitoring}

To evaluate the SBR performance on phosphorus removal by biological and co-precipitation processes, a monitoring plan was conducted by sample collection and analysis of physicochemical parameters, as well as biological activity analysis. Samples were collected fortnightly from the SBR inlet and outlet, as well as in the sludge (mixed liquor) during the last oxic stage (nitrification condition). Additionally, the sludge was submitted to bench tests to determine the oxygen uptake rate (OUR), the activity of phosphorus-accumulating organisms (PAOs), and denitrifying polyphosphate accumulating organisms (DPAOs).

\section{Physicochemical Analysis}

The following physicochemical parameters were analyzed: dissolved oxygen (DO), $\mathrm{pH}$, nitrate nitrogen $\left(\mathrm{N}-\mathrm{NO}_{3}\right)$, nitrite nitrogen $\left(\mathrm{N}-\mathrm{NO}_{2}\right)$, orthophosphate $\left(\mathrm{P}-\mathrm{PO}_{4}\right)$, chemical oxygen demand (COD - total and soluble), biochemical oxygen demand (BOD), total phosphorus (TP), total Kjeldahl nitrogen (TKN), ammonia nitrogen $\left(\mathrm{N}-\mathrm{NH}_{3}\right)$, alkalinity, volatile and 
total suspended solids (VSS, TSS), total dissolved solids (TDS) and sludge volume index (SVI). The dissolved oxygen concentration and $\mathrm{pH}$ were measured online using a probe (HACH - model DQ40d multi). $\mathrm{N}-\mathrm{NO}_{3}, \mathrm{~N}-\mathrm{NO}_{2}$ and $\mathrm{P}-\mathrm{PO}_{4}$ were quantified by ion chromatography (DIONEX - ICS-5000, Thermo Scientific). All the analyses were conducted according to Standard Methods (APHA, 2012).

\section{Biological activity assessment}

The oxygen uptake rate (OUR) was assessed according to Ochoa et al. (2002). It was measured in suspended biomass using a closed respirometry unit under three different conditions, in order to obtain: (1) endogenous OUR; (2) oxygen consumption during nitrification without a carbon source; and (3) exogenous respiration rate with a carbon source and allylthiourea, which is a nitrification inhibitor. The active heterotrophic $\mathrm{X}_{\mathrm{H}}\left(\mathrm{mg} \mathrm{COD}_{\mathrm{T}} \cdot \mathrm{L}^{-1}\right)$ and autotrophic biomasses $\mathrm{X}_{\mathrm{A}} \quad\left(\mathrm{mg} \quad \mathrm{COD}_{\mathrm{T}} \mathrm{L}^{-1}\right)$ were calculated according to Activated Sludge Model No. 1 (ASM1) (Henze et al., 1987).

The phosphorus uptake rate (PUR) tests were conducted according to the adapted methodology of Monclús et al. (2010). Samples of activated sludge from the SBR were analyzed to determine the PAOs and DPAOs activity under anoxic and anaerobic conditions, i.e. the phosphorus uptake and release rates of the active biomass present after being incubated anaerobically. The phosphate uptake rates (PURs) were estimated from the linear regression of phosphorus concentrations, and the ratio of anoxic PUR to aerobic PUR (anoxic/aerobic PUR ratio) was used as an index that reflected the fraction of DPAOs.

In addition, the microorganisms were identified using fluorescence in situ hybridization(FISH)(Amann, 1990). Samples were fixed in 4\% paraformaldehydephosphate-buffered saline and placed on $0.1 \%$ gelatin and $0.01 \% \mathrm{KCr}\left(\mathrm{SO}_{4}\right)_{2}$ gelatin-coated glass slides. The probes used for bacterial identification are shown in Table 1; probe details are available at probeBase. Microbial cells were detected by staining with $1 \%$ 4,6-diamidino-2-phenylindol (DAPI). The slides were then examined by microscopic analysis (Olympus BX41). All samples were analyzed against DAPI staining, which was considered $100 \%$.

\section{RESULTS AND DISCUSSION}

\section{SBR efficiency}

The average values for physicochemical parameters and the evaluated efficiency are found in Table 2. Considering the operation period for phase I and phase II, the findings showed that the phosphorus removal efficiency strongly improved during the coprecipitation operation.

As demonstrated in Table 2, the $\mathrm{pH}$ values remained stable and suitable for P removal processes. In spite of a

Table 1. Probe, specificity, and sequences used for fluorescence in situ hybridization (referenced from probeBase).

\begin{tabular}{|c|c|c|}
\hline Probe & Specificity & Sequence (5'-3') \\
\hline EUB mix (I+II+III) & $\begin{array}{l}\text { Mosto f Bacteria, Planctomucetales and } \\
\text { Verrucomicrobiales }\end{array}$ & $\begin{array}{l}\text { I: ctgectccegtagca } \\
\text { II: cagccaccetaggtgtctg } \\
\text { III: ccacccgtaggtgt }\end{array}$ \\
\hline PAO mix (462+651+846) & $\begin{array}{l}\text { Rhodocyclus-related PAO in } \\
\text { Betaproteobacteria }\end{array}$ & $\begin{array}{l}\text { ccgtcatctacwcagggtattaac } \\
\text { ccctctgccaaactccag } \\
\text { gttagctacggcactaaaagg }\end{array}$ \\
\hline GAO mix $(431+989)$ & Candidatus "Competibacter phosphatis" & $\begin{array}{l}\text { tccccgcctaaagggett } \\
\text { ttccccggatgtcaaggc }\end{array}$ \\
\hline $\begin{array}{l}\text { NOS } 190 \\
\text { PAF }\end{array}$ & $\beta$-Ammonium oxidizing & cgatcccetgctttctcc \\
\hline
\end{tabular}

Table 2. Average values of physicochemical parameters and the efficiency of the SBR in both phases.

\begin{tabular}{|c|c|c|c|c|c|c|}
\hline \multirow[t]{2}{*}{ Parameters } & \multicolumn{3}{|c|}{$\begin{array}{l}\text { Phase I: Biological treatment } \\
n=4\end{array}$} & \multicolumn{3}{|c|}{$\begin{array}{c}\text { Phase II: Co-precipitation } \\
n=5\end{array}$} \\
\hline & Influent & Effluent & $(\%)^{*}$ & Influent & Effluent & $(\%)^{*}$ \\
\hline $\mathrm{pH}^{* *}$ & $7.7 \pm 0.6$ & $7.3 \pm 0.6$ & - & $8.0 \pm 0.2$ & $7.4 \pm 0.3$ & - \\
\hline $\mathrm{DO}^{* *}\left(\mathrm{mg} \cdot \mathrm{L}^{-1}\right)$ & $0.5 \pm 0.4$ & $0.9 \pm 0.5$ & _ & $0.4 \pm 0.3$ & $0.8 \pm 0.5$ & - \\
\hline Alkalinity $\left(\mathrm{mgCaO}_{3} \cdot \mathrm{L}^{-1}\right)$ & $487 \pm 134$ & $208 \pm 199$ & - & $445 \pm 84$ & $175 \pm 72$ & - \\
\hline $\mathrm{TP}\left(\mathrm{mg} \cdot \mathrm{L}^{-1}\right)$ & $15.6 \pm 5.3$ & $9.0 \pm 4.4$ & $42 \%$ & $19 \pm 17$ & $1.2 \pm 1.3$ & $93 \%$ \\
\hline $\mathrm{P}_{-} \mathrm{PO}_{4}^{-3}\left(\mathrm{mg} \cdot \mathrm{L}^{-1}\right)$ & $11.0 \pm 5.0$ & $6.6 \pm 3.1$ & $39 \%$ & $7.8 \pm 4.0$ & $1.0 \pm 0.8$ & $87 \%$ \\
\hline $\mathrm{N}-\mathrm{NH}_{3}\left(\mathrm{mg} . \mathrm{L}^{-1}\right)$ & $53 \pm 21$ & $19 \pm 2$ & $64 \%$ & $63 \pm 13$ & $22.8 \pm 12.4$ & $64 \%$ \\
\hline $\mathrm{N}-\mathrm{NO}_{2}\left(\mathrm{mg} . \mathrm{L}^{-1}\right)$ & $0.2 \pm 0.4$ & $7.0 \pm 7.0$ & - & $0.1 \pm 0.3$ & $0.2 \pm 0.1$ & - \\
\hline $\mathrm{N}-\mathrm{NO}_{3}\left(\mathrm{mg} \cdot \mathrm{L}^{-1}\right)$ & $0.1 \pm 0.2$ & $9.2 \pm 6.8$ & - & $0.0 \pm 0.0$ & $1.4 \pm 1.6$ & - \\
\hline $\operatorname{COD}\left(\mathrm{mg} . \mathrm{L}^{-1}\right)$ & $255 \pm 84$ & $65.5 \pm 16.5$ & $74 \%$ & $762 \pm 662$ & $51 \pm 9$ & $93 \%$ \\
\hline $\operatorname{SCOD}\left(\mathrm{mg} . \mathrm{L}^{-1}\right)$ & $113 \pm 29$ & $35 \pm 11$ & $69 \%$ & $119 \pm 26$ & $44 \pm 11$ & $63 \%$ \\
\hline $\mathrm{BOD}_{5}\left(\mathrm{mg} \cdot \mathrm{L}^{-1}\right)$ & $177 \pm 27$ & $35 \pm 22$ & $80 \%$ & $532 \pm 348$ & $38 \pm 11$ & $93 \%$ \\
\hline $\operatorname{TDS}\left(\mathrm{mg} . \mathrm{L}^{-1}\right)$ & $215 \pm 154$ & $291 \pm 82$ & - & $500 \pm 44$ & $440 \pm 150$ & $12 \%$ \\
\hline
\end{tabular}

* Removal efficiency; average value \pm standard deviation; $n=$ number of samples. ** On-line samples. 
slight $\mathrm{pH}$ increase observed during the co-precipitation operation, derived from raw sewage (influent), the effluent of both phases was similar and remained in the range of 7.3 to 7.4. According to Ong et al. (2013), a pH close to 8.0 leads to better biological phosphorus removal efficiency. This fact is confirmed by Jeon et al. (2001), where the authors confirmed that, at this $\mathrm{pH}$ value, PAOs use more ATP (adenosine triphosphate) as an energy source than NADH (nicotinamide adenine dinucleotide) during acetate consumption. ATP is the main energy source for PAO, as well as NADH for glycogen accumulating organisms (GAO). It is important to remember that ATP production and new cell growth are basic mechanisms for phosphorus uptake from wastewater.

By contrast, Szabó et al. (2008) showed that a pH range between 6.0 and 7.5 is better for phosphorus chemical precipitation in wastewater treatment plants (WWTP). The $\mathrm{pH}$ values found in the present study appear suitable for both chemical precipitation and biological removal. De Haas et al. (2000) assessed organic and chemical precipitation simultaneously finding stable $\mathrm{pH}$ values ranging from 7.0 to 7.7 at the dosing point. Considering $\mathrm{FeCl}_{3}$ as precipitant, which is an acidic solution, $\mathrm{pH}$ and alkalinity decreases were expected in the final effluent, which can cause the death of cells inside the SBR. However, Fulazzaky et al. (2014) verified that most nitrifying bacteria can assimilate nitrogen and phosphorus, and incorporate it via cell growth and reproduction with a $\mathrm{pH}$ range of 5.61-6.64.

Considering the role of $\mathrm{pH}$ stability, the alkalinity is an important parameter for both chemical and biological removal processes. Hoffmann et al. (2007), studying a pilot SBR, revealed that the alkalinity must remain over $75 \mathrm{mg} \mathrm{CaCO} \mathrm{L}_{3} \cdot \mathrm{L}^{-1}$ to avoid the disruption of floc structure and a decrease in biomass activity. In the present study, the alkalinity values remained between $487 \pm 134 \mathrm{mg} \mathrm{CaCO}{ }_{3} \cdot \mathrm{L}^{-1}$ (phase I) and $445 \pm 84$ $\mathrm{mg} \mathrm{CaCO} \cdot \mathrm{L}^{-1}$ (phase II), considered suitable to support buffering. On the other hand, Szabó et al. (2008) affirms that high influent alkalinity reduces phosphorus removal efficiency by precipitation, due to a possible competition between carbonate and phosphate ions. In accordance, Ge et al. (2018) stated that alkaline conditions lead to a decrease of $\mathrm{P}$ removal, since the surface of metal hydroxide precipitant becomes more negatively-charged, which then strengthens the electrostatic repulsion between the $\mathrm{P}$ ions and metal hydroxide.

The availability of an organic carbon source, represented by the COD/BOD ratio, is an important factor in the phosphorus uptake metabolism of heterotrophic organisms. Thus, the COD/BOD ratios found were 1.44 and 1.43 in phases I and II, respectively, indicating a good potential of biodegradability.
However, the influent COD and BOD concentrations were lower during phase I (255 mgCOD.L $\mathrm{L}^{-1}$ and 177 mgBOD.L $\left.{ }^{-1}\right)$ than phase II (765 mgCOD.L $\mathrm{L}^{-1}$ and 532 mgBOD. $L^{-1}$ ) and, according to Metcalf \& Eddy (2003), it can be considered to be low-strength wastewater. By contrast, ammonium and phosphate concentrations were higher (53 mg NH $3 . \mathrm{L}^{-1}$ and $11 \mathrm{mg} \mathrm{PO} \mathrm{PO}_{4} \cdot \mathrm{L}^{-1}$ ) during phase I, conferring on the wastewater a C:N:P ratio of 10:2:1. The P/COD ratios of 0.06 and 0.02 for phases I and II, respectively, were favorable for the biological treatment. These ratios could be explained by the sewage origin, which presents more urine content than a usual sanitary wastewater. Table 2 shows the large difference in the raw sewage organic load between phases I and II and the high BOD removal efficiency, reaching $80 \%$ (phase I) and 93\% (phase II). These results of organic matter consumption in the reactor indicate a suitable operation and a biomass stability.

The applied organic loads were on average 0.105 $\mathrm{kg}$ COD $\cdot \mathrm{m}^{-3} \cdot \mathrm{d}^{-1}$ (phase I) and $0.660 \mathrm{~kg} \mathrm{COD} \cdot \mathrm{m}^{-3} \cdot \mathrm{d}^{-1}$ (phase II ), resulting in loads approximately six times greater in phase II. The low food availability during a long period could probably have impaired the activity of PAOs, reducing the efficiency of biological phosphorus removal in phase I. In agreement, the F:M (food: microorganisms) ratio found in phase I (0.07 kgBOD. $\mathrm{kgVSS}^{-1}$ ) was much lower than the F:M ratio during phase II $\left(0.40 \mathrm{kgBOD} \cdot \mathrm{kgVSS}^{-1}\right)$. On the other hand, the COD / SCOD ratio was lower during phase I (2.2 compared to 6.4 in phase II) where almost half of the total COD was soluble (Table 2). This means that the food readily available for the microbiota was quite similar in both phases, in spite of the strong difference of total COD. Moreover, the total COD removal efficiency was higher in phase II, while the SCOD efficiency was higher in phase I, showing the effect of precipitant in particulate COD removal and biological activity inhibition. This effect is discussed further in the biological analysis section.

Considering nitrogen removal in Table 2, it is evident that the denitrification process in phase I could not reach the suitable equilibrium with nitrification entailing nitrite and nitrate accumulation. However, the higher nitrate removal in phase II is not necessarily attributed to denitrifying because ferric chloride could cause the precipitation of both anions (nitrite and nitrate). According to Philips at al. (2003) the decrease in nitrification and denitrification could be an indirect consequence of the effect of the iron salts on the floc structure, where $\mathrm{Fe}(\mathrm{III})$ produced small, weak flocs, with high amounts of protozoa. Due to the difficult settling of these small flocs, the nitrifying community can be washed out of the reactor, thus causing decreased efficiency.

During phase I, with biological treatment for phosphorus removal, the removal efficiencies were 
unsatisfactory, reaching $39 \%$ for orthophosphate and $41 \%$ for total phosphorus (TP). An average TP concentration of $9.0 \pm 4.4 \mathrm{mg} . \mathrm{L}^{-1}$ was measured in the effluent, exceeding the discharge limits (Santa Catarina State Law 14.675/09 - 4.0 mgTP.L ${ }^{-1}$ or $75 \%$ of efficiency for total phosphorus removal) (Table 2 and Figure 2). Costa et al. (2013), assessing bacterial phosphorus assimilation by SBR, showed a phosphorus removal efficiency of $54 \%$ during aerobic condition, while the average concentrations decreased from 26 to $12 \mathrm{mgPO}_{4} \cdot \mathrm{L}^{-1}$. However, during the anoxic condition, a small amount of phosphate was released, and the $\mathrm{PO}_{4}$ concentration increased from 12 to $14 \mathrm{mg} . \mathrm{L}^{-1}$ with COD consumption.

An efficiency improvement was observed in phase II (co-precipitation) with the TP removal efficiency reaching 93\% using the precipitant $\mathrm{FeCl}_{3}$. Similar results were obtained by Filali-Meknassi et al. (2005) treating slaughterhouse wastewater, with a dosage of $6000 \mathrm{mg} \mathrm{FeCl}{ }_{3} 6 \mathrm{H}_{2} \mathrm{O} . \mathrm{L}^{-1}$ where the total phosphorus removal efficiency achieved 96\%. The high TP removal efficiencies were maintained even after the strong increase of phosphorus concentration in the influent $\left(50 \mathrm{mg}\right.$ TP. $\left.\mathrm{L}^{-1}\right)$. This fact may indicate the operational stability of co-precipitation that supported a high range of raw wastewater concentration.

Considering the particulate and soluble portions, it was noted that the TP: $\mathrm{PO}_{4}$ ratio was reasonably higher during phase II (2.4) than phase I (1.4). This unintentional fact may have implied improved performance for both strategies, since the low TP: PO4 ratio indicates more phosphorus in the soluble form, favoring biological removal. The opposite (more phosphorus in the particulate form) may favor precipitation. Regarding the real sewage condition, this range could be attributed to toilet use by the office staff (more urine and detergents), resulting in more soluble phosphate. As mentioned before, the same behavior was observed with the COD/SCOD ratio.

Considering the high variation in influent TP concentration and constant $\mathrm{FeCl}_{3}$ applied, a large range in the Fe:P ratio was observed, ranging from $6: 1$ to 0.75:1 in terms of molar concentration. De Haas et al.

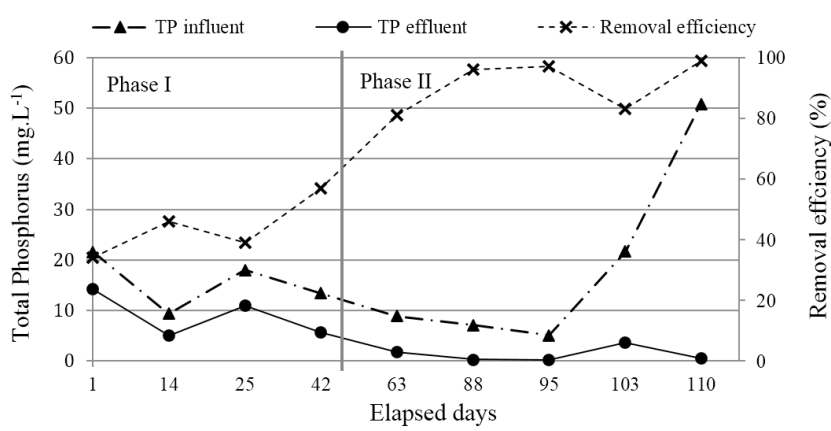

Figure 2. Phosphate concentration and efficiency during the whole period evaluated, in phases I and II.
(2000), using pilot plants for co-precipitation, found that 0.75 of precipitated phosphorus per each mol of Fe added is a suitable ratio when the initial phosphorus concentrations are greater than $10 \mathrm{mg} . \mathrm{L}^{-1}$. However, the authors stated that no consensus for the optimal Fe:P molar ratio is established, with values ranging from 0.80 to 7.17 reported for different biological treatment systems in the literature. Filali-Meknassi et al. (2005) applied a molar Fe:P ratio of 1.73 to achieve a P concentration below $1 \mathrm{mg}$ P.L. $\mathrm{L}^{-1}$ in the SBR effluent. Li et al. (2014) applied different ranges of the Fe:P molar ratio (from 1.5 to 2.7 ) to verify the performance of the anoxic reactor on co-precipitation. An Fe:P molar ratio of 2.0-2.2:1 showed satisfactory soluble phosphorus (SP) removal, resulting in an average final SP concentration ranging from 0.48 to $0.76 \mathrm{mg} / \mathrm{L}$.

Moreover, a reduction in SVI was observed from phase I $\left(85 \mathrm{~mL} . \mathrm{g}^{-1}\right)$ to phase II $\left(66 \mathrm{~mL} \cdot \mathrm{g}^{-1}\right)$. Zhang et al. (2013) also obtained a decrease in SVI from 126 $\mathrm{mL} \cdot \mathrm{g}^{-1}$ to $98 \mathrm{~mL} \cdot \mathrm{g}^{-1}$, indicating that co-precipitation could improve sludge settleability. According to Metcalf \& Eddy (2003), SVI values below $100 \mathrm{~mL} \cdot \mathrm{g}^{-1}$ indicated a good sludge settleability. The VSS/TSS ratio decreased from phase I to phase II (0.41 to 0.22$)$, indicating a significant biodegradation reduction due to the addition of $\mathrm{FeCl}_{3}$. However, the TDS remained during both phases (Table 2) in accordance with the discharge limits (Santa Catarina State Law 14.675/09 - $500 \mathrm{mg}$ TDS.L $\left.\mathrm{L}^{-1}\right)$.

\section{Biological analysis}

During phase I, the optical microscopic analysis showed heterogeneous sludge samples with regular size of flocs within well-structured colonies. The flocs were comprised of irregular arrangements of cocci and rod cells, suspended matter. The occurrence of filamentous organisms was low in many samples. As expected, FISH analysis revealed the predominance of bacteria presenting $85 \%$ of DAPI-stained cells for EUBmix (Figure 3). These percentages of bacteria abundance in activated sludge flocs were also reported in previous studies (Wong et al., 2005; Fernandes et al., 2013; Mehlig et al., 2013).

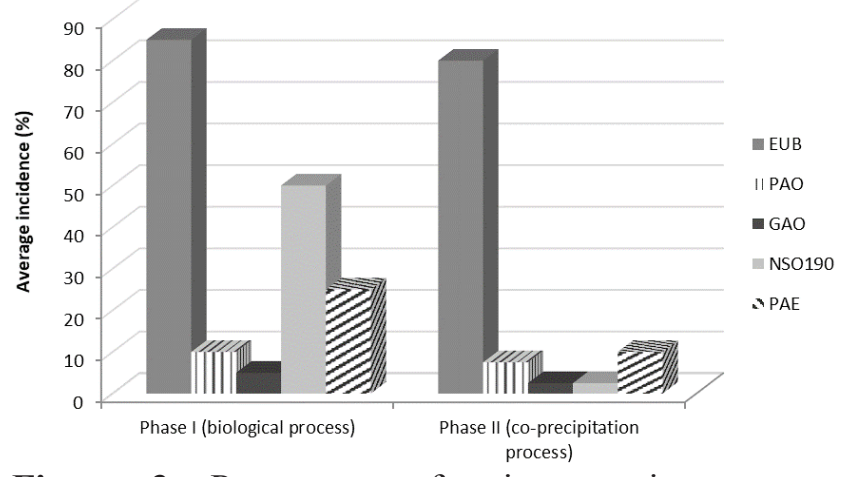

Figure 3. Percentage of microorganism groups obtained in FISH analysis. 
PAOs (Candidatus "Accumulibacter" cluster) were found at low concentrations (average 10\% of DAPI-stained cells) as demonstrated in Figure 3. PAOs are favored in SBRs because of their competitive advantages over non-poly-P accumulating microorganisms and their ability to survive during food shortage periods. However, the low food availability (COD concentration) and the competition for carbon source with GAOs may have caused lower biological $P$ removal efficiency in this study (phase I). In some plants, specially designed and operated for P removal, PAO abundance could reach $80 \%$ of DAPI-stained cells (Oehmen et al., 2007; Nielsen et al., 2009; Zou and Wang, 2016). However, in most common activated sludge plants, Candidatus "Accumulibacter" comprises on average only $13 \%$ of DAPI (Mehlig et al., 2013).

The findings revealed that biological $\mathrm{P}$ removal (phase I) was possible. In spite of low carbon availability, the total phosphorus removal efficiency reached $42 \%$. These results are consistent with other studies of biological P removal in SBR (Fernandes et al. 2014; Jafarzadeh et al., 2014).

When the food/microorganisms ratio is constantly low, as presented in this study, PAOs are unable to produce ATP and new cells efficiently, decreasing biological $\mathrm{P}$ removal. In this case, the operation requires complementary chemical precipitation to improve the removal efficiency of phosphorus.

Regarding the co-precipitation period (phase II), bacteria predominance was also high $(80 \%$ of DAPIstained cells for EUBmix) and no influence of ferric chloride addition was observed. Compared to phase $\mathrm{I}$, the relative presence of active PAOs and GAOs decreased from 10 to $7.5 \%$ (PAOs) and from 5 to 2.5\% (GAOs) during phase II (Figure 3). Despite the observed decrease in the presence of PAOs and GAOs, it is not possible to assert that it occurred due to $\mathrm{FeCl}_{3}$ addition.

Denitrifying organisms could appear to be more negatively affected during phase I due to nitrate accumulation, as observed in Table 2. However, it is important to note that ferric chloride can cause precipitation of anions, such as nitrate, removing it from the water column (Philips et al. 2003). Thus, the nitrate removal observed in phase II was probably not due to denitrification, but precipitation. Also, Fe (III) can serve as an electron acceptor for organic matter oxidation, neutralizing the nitrate function in the denitrifying metabolism. Supporting this, the FISH analysis of PAE (Pseudomonas spp population) showed a significant reduction of relative abundance from phase I (25\%) to phase II (10\%).

Through specific oxygen uptake rate (OUR $)$ assays, it was possible to show that the DO consumption velocity was higher during phase II than phase I, for both autotrophic and heterotrophic metabolism (Table 3 ). It could be inferred that chemical precipitant does not affect the respiration metabolism of the microorganisms in SBR mixed liquor. Fernandes et al. (2014) achieved OUR $\left(\mathrm{mgO}_{2} \cdot \mathrm{gVSS}^{-1} \cdot \mathrm{h}^{-1}\right)$ values two to four times greater (5.51 and 11.42 for nitrifying and heterotrophic biomass, respectively) in a fullscale step-feed SBR for urban wastewater treatment. According to the authors, the dissolved oxygen uptake and aerobic microbial respiration of a system are closely linked and are particularly sensitive to changes in microbial activity.

The results of active autotrophic and heterotrophic biomass presented in Table 4, corroborated the results of FISH analysis, where the percentage of nitrifying and denitrifying organisms decreased in phase II. The active heterotrophic biomass (represented by denitrifying organism) dropped from approximately $212 \mathrm{mg}$. COD. $\mathrm{L}^{-1}$ in phase I to $47 \mathrm{mgCOD} . \mathrm{L}^{-1}$ in phase II. Additionally, the active autotrophic biomass was lower during phase II (2.87 mgCOD.L $\left.{ }^{-1}\right)$ compared to phase I (26.43 mgCOD. $\left.\mathrm{L}^{-1}\right)$. An overall reduction of active biomass concentration (heterotrophic and autotrophic biomass) of $80 \%$ was verified during phase II (Table 4), indicating a possible effect of chemical precipitant on biomass concentration. The species composition and concentration depend on wastewater composition and system operation; changes in growth conditions such $\mathrm{pH}$, temperature, alkalinity, and dissolved oxygen may determine diversity of species (Daims et al., 2009; Fernandes et al., 2014).

The sludge capacity for the biological phosphorus uptake rate (PUR) from wastewater is represented in Figure 4 for both phases. Considering phase I, the phosphate concentration increased during the anaerobic condition, however, the phosphorus released

Table 3. Oxygen uptake rates (OUR) obtained during both evaluated phases.

\begin{tabular}{|c|c|c|c|c|}
\hline Phases & Metabolism & $\begin{array}{c}\text { OUR } \\
\left(\mathrm{mgO}_{2} \cdot \mathrm{L}^{-1} \cdot \mathrm{h}^{-1}\right) \\
\end{array}$ & $\begin{array}{l}\text { VSS } \\
\left(g . L^{-1}\right)\end{array}$ & $\begin{array}{c}\text { OUR }_{\mathrm{s}}{ }^{*} \\
\left(\mathrm{mgO}_{2} \cdot \mathrm{gTSS}^{-1} \cdot \mathrm{h}^{-1}\right) \\
\end{array}$ \\
\hline \multirow{3}{*}{$\begin{array}{c}\text { Phase I } \\
\text { (Biological P removal) }\end{array}$} & Endogenous & 8.71 & 1.80 & 4.86 \\
\hline & Nitrifying & 2.56 & 1.80 & 1.43 \\
\hline & Exogenous & 5.85 & 1.80 & 3.26 \\
\hline \multirow{3}{*}{$\begin{array}{c}\text { Phase II } \\
\text { (Co-precipitation) }\end{array}$} & Endogenous & 1.03 & 1.09 & 0.95 \\
\hline & Nitrifying & 2.65 & 1.09 & 1.48 \\
\hline & Exogenous & 6.87 & 1.09 & 6.31 \\
\hline
\end{tabular}

* Specific oxygen uptake rate in terms of TSS present in the mixed liquor sample. 
Table 4. Activity of autotrophic $\left(\mathrm{X}_{\mathrm{A}}\right)$ and heterotrophic $\left(\mathrm{X}_{\mathrm{H}}\right)$ organisms in phases I and II.

\begin{tabular}{cccc}
\hline Phase & \multicolumn{1}{c}{ Active Biomass } & $\%$ \\
\hline \multirow{2}{*}{ Phase I - Biological P removal } & $\mathrm{X}_{\mathrm{A}}\left(\mathrm{mg}\right.$ COD. $\left.\mathrm{L}^{-1}\right)$ & 26.43 & 11.0 \\
& $\mathrm{X}_{\mathrm{H}}\left(\mathrm{mg}\right.$ CODT. $\left.\mathrm{L}^{-1}\right)$ & 211.82 & 89.0 \\
\hline \multirow{2}{*}{ Phase II - Co-precipitation } & $\mathrm{X}_{\mathrm{A}}\left(\mathrm{mg}\right.$ COD. $\left.\mathrm{L}^{-1}\right)$ & 2.87 & 6.0 \\
& $\mathrm{X}_{\mathrm{H}}\left(\mathrm{mg}\right.$ COD. $\left.\mathrm{L}^{-1}\right)$ & 46.82 & 94.0
\end{tabular}

was not totally absorbed during the aerobic condition by PAOs, but DPAO could have done it (Figure 4a). Different than expected, the $\mathrm{P}$ uptake rate was higher for DPAO $\left(1.09 \mathrm{mgPO}_{4} \cdot \mathrm{g}^{-1} \cdot \mathrm{VSS}^{-1}\right)$ than PAO $(0.69$ $\left.\mathrm{mgPO}_{4} \cdot \mathrm{g}^{-1} \cdot \mathrm{VSS}^{-1}\right)$, corresponding to DPAO activity of $63 \%$. In contrast, Monclús et al. (2010) reported different behavior, presenting a DPAO PUR of 5.08 $\mathrm{mgPO}_{4} \cdot \mathrm{g}^{-1} \cdot \mathrm{VSS}^{-1}$ and PAO PUR of $13.60 \mathrm{mgPO}_{4} \cdot \mathrm{g}^{-1}$. $\mathrm{VSS}^{-1}$, corresponding to $37 \%$ of DPAO activity. However, Fernandes et al. (2013) reported DPAO activity of $70 \%$ in a full-scale SBR, with the higher activity of this group justified by low DO levels (0.3 $\left.\mathrm{mgDO} . \mathrm{L}^{-1}\right)$ and nitrate availability, as well as in the present study where average DO concentration was $0.9 \mathrm{mg} . \mathrm{L}^{-1}$.

Considering co-precipitation (phase II), the PAOs phosphorus uptake rate was negative, whereas for DPAOs, PUR reached $0.62 \mathrm{mgPO} \cdot \mathrm{g}^{-1} \cdot \mathrm{VSS}^{-1}$. This result may be assigned to PAO inhibition and phosphate immobilization by $\mathrm{FeCl}_{3}$. Puig (2007), studying $\mathrm{P}$ uptake rate under different carbon sources and adaptation times, related values between 0.7 and $7.0 \mathrm{mgPO}_{4} \cdot \mathrm{g}^{-1} \cdot \mathrm{VSS}^{-1}$, showing that PUR is affected by parameters such as the configuration of the system and the influent characteristics. Thus, a sequence of anaerobic-anoxic-aerobic phases with multiple feeding events is a promising strategy for removing nutrients from wastewater. Moreover, the removal performance is strongly influenced by the $\mathrm{C}: \mathrm{N}: \mathrm{P}$ influent ratios. If the carbon concentration is not high enough, the first process affected is the phosphorus removal.

The overall better efficiency of DPAO's phosphorus uptake compared to PAO's PUR could be explained by DPAO's capacity to use the abundant nitrates during anoxic phases and their apparent advantage over GAOs during carbon source competition. Figure $4 \mathrm{~b}$ demonstrated the inhibition of biological phosphorus uptake during phase II. Phosphorus absorption did not
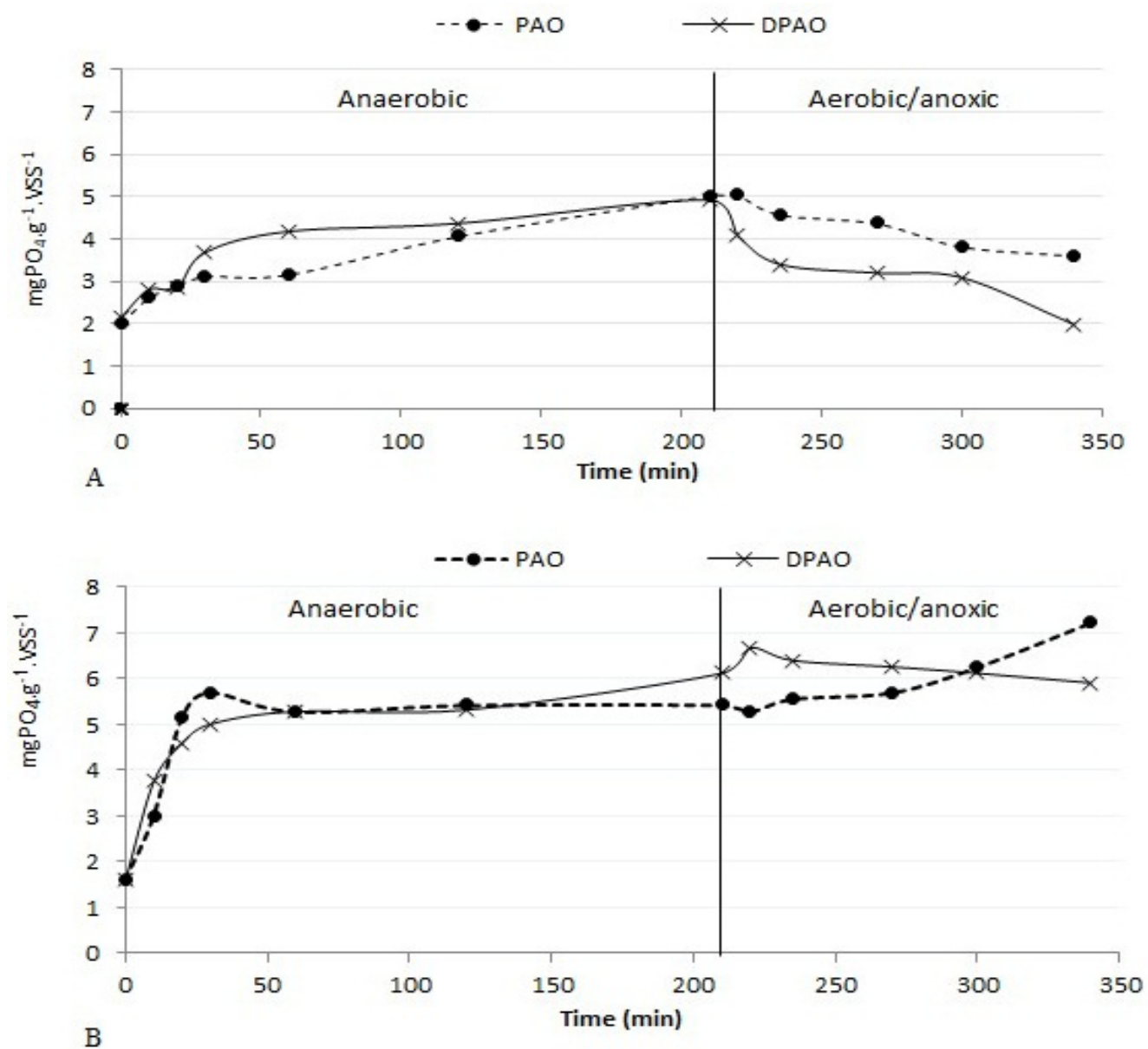

Figure 4. PAOs and DPAOs activities during bench tests for phases I and II (figures A and B respectively). 
occur in the aerobic condition, resulting in negative phosphorus removal efficiency at the end of the test.

\section{CONCLUSIONS}

The findings demonstrated that co-precipitation could enhance the efficiency of phosphorus removal, mainly for effluents with a low C:P ratio, where the EBPR process is normally limited. However, the addition of $\mathrm{FeCl}_{3}$ could have detracted from the denitrifying organisms' activity, even in suitable dosage - a fact which must be observed.

FISH analyses did not demonstrate a strong PAOs inhibition, although nitrifying and denitrifying organisms (NSO and PAE) showed a significant reduction during phase II (with ferric chloride). Additionally, an overall reduction of active heterotrophic and autotrophic biomass concentration of $80 \%$ was noted during phase II, indicating a possible metabolic inhibition effect of the chemical precipitant on biomass concentration. The bench tests showed the higher activity of DPAOs over PAOs, mainly for phase I, without ferric chloride.

\section{ACKNOWLEDGMENTS}

The authors would like to thank the Brazilian Coordination for the Improvement of Higher Education Personnel (CAPES) and the Brazilian National Research and Development Council (CNPq), for their financial support. The authors are also grateful to the researchers of the Laboratory of Liquids and Gaseous Effluents (LABEFLU) at the Federal University of Santa Catarina (UFSC - Brazil) for assistance. The authors thank Rotária do Brasil Company for providing the access to their SBR and allowing the operation of the experimental configuration proposed in this study.

\section{REFERENCES}

Akin, B. S., Ugurlu, A. Monitoring and control of biological nutrient removal in a Sequencing Batch Reactor. Process Biochemistry, 40, 2873-2878 (2005). https://doi.org/10.1016/j. procbio.2005.01.001

Amann, R. I., Krumholz, L., Stahl, D. A. Fluorescent oligonucleotide probing of whole cells for determinative, phylogenetic, and environmental studies in microbiology. Journal of Bacteriology, 172, $762-770$ (1990). https://doi.org/10.1128/ jb.172.2.762-770.1990

APHA, American Public Health Association Standard Methods for the Examination of Water and Wastewater. 21st Edition, APHA, AWWA (American Water Works Association), and WEF (Water Environment Federation), Washington DC (2005).
Artan, N., Orhon, D. Mechanism and design of sequencing batch reactors for nutrient removal. In: IWA Publishing. Scientific and Technical Report, 19, 99 pp. (2005).

Costa, R. H. R., Wolff, D. B., Souto, V. S. Performance and kinectics aspects of nitrogen removal in a biofilm sequencing batch reactor. Int. J. Environ. Res., 7, 513-522 (2013).

Cui, Y. W., Wang, S. Y., Li, J. On-line monitoring for phosphorus removal process and bacterial community in sequencing batch reactor, Chin. J. Chem. Eng., 17, 484-492 (2009). https://doi. org/10.1016/S1004-9541(08)60235-9

Daims, H., Maixner, F., Schmid, M. The Nitrifying Microbes: Ammonia Oxidizers, Nitrite Oxidizers, and Anaerobic Ammonium Oxidizers. In Fish Handbook for Biological Wastewater Treatment; Nielsen, P., Daims, H., Lemmer, H., Eds.; IWA Publishing: London, U.K. 123 pp. (2009).

De Haas, D. W., Wentzel, M. C., Ekama, G. A. The use of simultaneous chemical precipitation in modified activated sludge systems exhibiting biological enhanced phosphate removal. Part 4: Experimental periods using ferric chloride. Water SA, 26, 485504 (2000).

ESPP (European Sustainable Phosphorus Platform) - EU Fertilizer Regulation revision - European essential requirements for organic fertilizers and recovered nutrients, Scope newsletter $n^{\circ}$ 98, $27 \mathrm{pp}$. (2013).

Fernandes, H., Hoffmann, H., Antonio, R. V., Costa, R. H. R. The Role of Microorganisms in a Full-Scale Sequencing Batch Reactor Under Low Aeration and Different Cycle Times. Water Environment Research, 86, 800-809 (2014). https://doi.org/10.2 175/106143013X13807328848450

Fernandes, H., Jungles, M. K., Hoffmann, H., Antonio, R. V., Costa, R. H. R., Full-scale sequencing batch reactor (SBR) for domestic wastewater: Performance and diversity of microbial communities. Bioresource Technolgy, 132, 262-258 (2013). https://doi.org/10.1016/j. biortech.2013.01.027

Filali-Meknassi, Y., Auriol, M., Tyagi, R. D., Comeau, Y., Surampalli, R. Y., Phosphorus Co-precipitation in the Biological Treatment of Slaughterhouse Wastewater in a Sequencing Batch Reactor. Practice Periodical of Hazardous, Toxic, and Radioactive Waste Management, July, 179-192 (2005). https:// doi.org/10.1061/(ASCE)1090-025X(2005)9:3(179)

Fulazzaky, M. A., Salim, N. A. A., Abdullah, N. H., Yusoff, A. R. M., Paul, E., Precipitation of ironhydroxy-phosphate of added ferric iron from domestic wastewater by an alternating aerobicanoxic process. Chemical Engineering Journal, 253, 291-297 (2014). https://doi.org/10.1016/j. cej.2014.05.049 
Ge, J., Meng, X., Song, Y., Terracciano, A. Effect of phosphate releasing in activated sludge on phosphorus removal from municipal wastewater. Journal of Environmental Sciences, 67, 216-223 (2018). https://doi.org/10.1016/j.jes.2017.09.004

Henze, M., Grady, C. P. L., Gujer, W., Marais, G. V. R., Matsuo, T., Activated sludge Model No1. IAWPRC Scientific and Technical Reports No 1. London UK (1987).

He, Y., Wang, Y., Song, X. High-effective denitrification of low $\mathrm{C} / \mathrm{N}$ wastewater by combined constructed wetland and biofilm-electrode reactor (CW-BER). Bioresour. Technol., 203, 245-251 (2016). https:// doi.org/10.1016/j.biortech.2015.12.060

Hoffmann, H., Costa, T. B., Wolff, D. B., Platzer, C., Costa, R. H. R. The Potential of Denitrification for the Stabilization of Activated Sludge Processes Affected by Low Alkalinity Problems. Brazilian Arch. Biol. Technol., 50, 329-337 (2007). https:// doi.org/10.1590/S1516-89132007000200018

Jafarzadeh, G. T., Mortezaeifar, S., Gholami, M., Rezaei Kalantary, R., Mahvi, A. H. Performance evaluation of enhanced SBR in simultaneous removal of nitrogen and phosphorous. Journal of Environmental Health Science \& Engineering, 12, 1-7 (2014). https://doi.org/10.1186/s40201-014-0134-2

Jeon, C. O., Lee, D. S., Park, J. M. Enhanced biological phosphorus removal in an anaerobic/ aerobic sequencing batch reactor: Characteristics of carbon metabolism, Water Environment Research, 73, 295-300 (2001). https://doi. org/10.2175/106143001X139308

Li, T., Wang, H., Dong, W., Liu, T., Ouyang, F., Zhang, Q., Dong, X. Performance of an anoxic reactor proposed before BAF: Effect of ferrous sulfate on enhancing denitrification during simultaneous phosphorous removal. Chemical Engineering Journal, 248, 41-48 (2014). https:// doi.org/10.1016/j.cej.2014.03.033

Marques, R., Santos, J., Nguyen, H., Carvalho, G., Noronha, J. P., Nielsen, P. H., Reis, M. A. M., Oehmen, A. Metabolism and ecological niche of Tetrasphaera and Ca. Accumulibacter in enhanced biological phosphorus removal. Water Research, 122, 159-171 (2017). https://doi.org/10.1016/j. watres.2017.04.072

Mehlig, L., Petzold, M., Heder, C., Günther, S., Müler, S., Eschenhagen, M., Röske, I., Röske, K. Biodiversity of Polyphosphate Accumulating Bacteria in eight WWTPs with Different Modes of Operation. Journal Environmental Engineering, 139, 1089-1098 (2013). https://doi.org/10.1061/ (ASCE)EE.1943-7870.0000711

Metcalf and Eddy, Inc. Wastewater Engineering: Treatment and Reuse. Boston: McGraw-Hill, 1819 pp. (2003).
Mielcarek, A., Rodziewicz, J., Janczukowicz, W., Thornton, A. The feasibility of citric acid as external carbon source for biological phosphorus removal in a sequencing batch biofilm reactor (SBBR). Biochem. Eng. J., 93, 102-107 (2015). https://doi. org/10.1016/j.bej.2014.10.001

Monclús, H., Sipma, J., Ferrero, G., RodriguesRoda, I., Comas, J. Biological Nutrient Removal in an MBR Treating Municipal Wastewater with Special Focus on Biological Phosphorus Removal. Bioresour. Technol., 101, 3984-3991 (2010). https://doi.org/10.1016/j.biortech.2010.01.038

Nielsen, J. L., Hansen, A. A. Identification of Denitrifying Microorganismsin Activated Sludge by FISH. In FISH Handbook for Biological Wastewater Treatment, Nielsen, P., Daims, H., Lemmer, H., Eds., IWA Publishing: London, U.K., 123 pp. (2009). https://doi.org/10.2166/9781780401775

Ochoa, J. C., Colprim, J., Palacios, B., Paul, E., Chatellier, P. Active Heterotrophic and Autotrophic Biomass Distribution Between Fixed and Suspensed Systems in a Hybrid Biological Reactor. Water Sci. Technol., 46, 397-404 (2002). https:// doi.org/10.2166/wst.2002.0507

Oehmen, A., Carvalho, G., Lopez-Vazquez, C. M., van Loosdrecht, M. C. M., Reis, M. A. M. Incorporating Microbial Ecology into the Metabolic Modelling of Polyphosphate Accumulating Organisms and Glycogen Accumulating Organisms. Water Res., 44, 4992-5004 (2010). https://doi.org/10.1016/j. watres.2010.06.071

Oehmen, A., Lemos, P. C., Carvalho, G., Yuan, Z., Keller, J., Blackall, L. L., Reis, M. A. M. Advances in enhanced biological phosphorus removal: from micro to macro scale. Water Research, 41, 2271-2300 (2007). https://doi.org/10.1016/j.watres.2007.02.030

Ong, Y. H., Chua, A. S. M., Lee, B. P., Ngoh, G. C. Long-term performance evaluation of EBPR process in tropical climate: star-up process stability and the effect of operational $\mathrm{pH}$ and influent $\mathrm{C}: \mathrm{P}$ ratio. Water Science \& Technology, 67, 340-346 (2013). https://doi.org/10.2166/wst.2012.552

Philips, S., Rabaey, K., Verstraete, W. Impact of iron salts on activated sludge and interaction with nitrite or nitrate. Bioresource Technology, 88, 229-239 (2003). https://doi.org/10.1016/S0960-8524(02)00314-0

Puig, S. B. Operation and control of SBR processes for enhanced biological nutrient removal from wastewater. Ph.D. Thesis, University of Girona (2007).

Santa Catarina State Law 14.675, State Environmental Code. Legislative Assembly of Santa Catarina. Brazil, 12 pp. (2009).

Sarparastzadeh, H., Saeedi, M., Naeimpoor, F., Aminzadeh, B. Pretreatment of Municipal Wastewater by Enhanced Chemical Coagulation. Int. J. Environ. Res., 1, 104-113 (2007). 
Schuler, A. J., Xiao, Y. Predicted Distributed State Effects on Enhanced Biological Phosphorus Removal in a 5-Stage Berdenpho Wastewater Treatment Configuration. Water Environ. Res., 80, 454-463 (2008). https://doi. org/10.2175/106143008X266797

Seviour, R. J., Mino, T., Onuki, M. The Microbiology of Biological Phosphorus Removal in activated Sludge Systems. Microbiol. Rev., 27, 99-127 (2003). https://doi.org/10.1016/S0168-6445(03)00021-4

Szabó, A., Takács I., Murthy, S., Daigger, G. T., Licsko, I., Smith, S. Significance of Design and Operational Variables in Chemical Phosphorus Removal. Water Science and Technology, 80, 407-416 (2008). https://doi.org/10.2175/106143008X268498

Wong, M. T., Mino, T., Seviour, R. J., Onukib, M., Liu, W.T. In situ identification and characterization of the microbial community structure of full-scale enhanced biological phosphorous removal plants in Japan. Water Research, 39, 2901-2914 (2005). https://doi.org/10.1016/j.watres.2005.05.015

Wu, G., Sorensen, K. B., Rodgers, M., Zhan, X. Microbial Community Associated with GlucoseInduced Enhanced Biological Phosphorus Removal. Water Sci. Technol., 60, 2105-2113 (2009). https:// doi.org/10.2166/wst.2009.545

Zhang, Z., Li, Y., Wei, L., Lü, Y., Wang, M., Gao, B. Effect of Ferric Chloride on the Properties of Biological Sludge in Co-precipitation Phosphorus Removal Process. Chinese Journal of Chemical Engineering, 21, 564-568 (2013). https://doi. org/10.1016/S1004-9541(13)60511-X

Zou, H., Wang, Y. Phosphorus removal and recovery from domestic wastewater in a novel process of enhanced biological phosphorus removal coupled with crystallization. Bioresource Technology, 211, 87-92 (2016). https://doi.org/10.1016/j. biortech.2016.03.073 
